\title{
PEMBENTUKAN RANAH AFEKTIF SISWA \\ DALAM PEMBELAJARAN FIKIH DI MA AL URWATUL WUTSQO BULUREJO DIWEK JOMBANG
}

\author{
Qurrotul Ainiyah \\ Prodi Pendidikan Agama Islam, STIT Al-Urwatul Wutsqo Jombang \\ e-mail:q_ainiy@yahoo.co.id \\ Suharti Puji Lestari \\ Prodi Pendidikan Agama Islam, STIT Al-Urwatul Wutsqo Jombang \\ e-mail: suharti.p13@yahoo.com
}

\begin{abstract}
Abstrak: Demanding knowledge is not just a transfer of knowledge for the benefit of the world, not just intelligence without thinking about spirituality and morals. So that learning must cover all aspects, from intelligence to moral intelligence for everyday life. The affective domain is very important, where today many people understand religion but have not yet practiced it, because affective values and religious values have not yet become a reflection of their daily attitudes. This study reveals the formation of students' affective domains in fiqh learning which is integrated with the Ahkam Tafsir at Al Urwatul Wutsqo Bulurejo DIwek Jombang which is manifested in the formation of attitudes and awareness of students to apply Islamic law in daily life.
\end{abstract}

Keywords:: establishment of afective facilities, learning of fiqh

\section{PENDAHULUAN}

Pendidikan mempunyai peran yang luhur dan agung, sifat yang agung ditunjukkan dari peran pendidikan dipahami sebagai pemberian bekal siswa untuk menghadapi masa depan, pendidikan juga di pahami sebagai sarana untuk pencerdasan seseorang. ${ }^{1}$ Pembentukan dan pengembangan sikap serta moral seorang siswa melalui pendidikan agama disekolah menjadi sangat penting. Menuntut ilmu bukan sekedar transfer ilmu untuk kepentingan dunia saja, bukan hanya untuk kecerdasan akal saja tanpa memikirkan spiritualitas dan akhlak. Sehingga belajar harus mencakup segala aspek, mulai kecerdasan akal hingga kecerdasan akhlak untuk kehidupan sehari hari. Dasar agama untuk membentuk pribadi yang agamis (bertaqwa) merupakan kebutuhan rohaniah dan juga kebutuhan akademis melalui ilmu pengetahuan. Pendidikan tidak hanya berorientasi pada ilmu pengetahuan (knowledge oriented) dan ketrampilan (skill oriented), namun juga pada nilai / sikap (value oriented). Proses pembelajaran yang

\footnotetext{
${ }^{1}$ Khoiriyah, Memahami Metodologi Studi Islam, (Yogyakarta; Penerbit Teras, 2013)., 8.
} 
menekankan pada nilai-nilai sikap (kejujuran, keharmonisan, saling menghargai, dan kesetaraan) adalah hal yang tidak boleh dikesampingkan, apalagi tidak di lakukan. ${ }^{2}$

Masalah afektif dirasakan penting oleh semua orang, namun implementasinya masih kurang. Hal ini disebabkan merancang pencapaian tujuan pembelajaran afektif tidak semudah seperti pembelajaran kognitif dan psikomotor. Satuan pendidikan harus merancang kegiatan pembelajaran yang tepat agar tujuan pembelajaran afektif dapat dicapai terutama dalam pembentukan dan pengembangan nilai spiritual, sikap dan moral siswa melalui pendidikan agama. Kemampuan afektif berhubungan dengan minat dan sikap yang dapat berbentuk tanggung jawab, kerjasama, disiplin, komitmen, percaya diri, jujur, menghargai pendapat orang lain, dan kemampuan mengendalikan diri. Semua kemampuan ini harus menjadi bagian dari tujuan pembelajaran di sekolah, yang akan dicapai melalui kegiatan pembelajaran yang tepat. Keberhasilan pendidik melaksanakan pembelajaran ranah afektif dan keberhasilan siswa mencapai kompetensi afektif perlu dinilai. Oleh karena itu perlu dikembangkan acuan pengembangan perangkat penilaian ranah afektif. ${ }^{3}$

Ranah afektif terlihat dalam sikap ,minat, apresiasi, nilai, dan emosi atau prasangka". " Ranah Afektif sangat penting dimana masa sekarang banyak orang paham agama akan tetapi belum mengamalkannya, karena nilai-nilai afektif dan nilai agama belum menjadi cerminan sikap kesehariannya. Contoh banyak pejabat yang mengerti agama tetap saja melakukan korupsi. Agama sebagai sebuah pranata untuk mengatur kehidupan manusia secara baik, memberikan pedoman pendidikan untuk membentuk karakter dan moral (akhlak mulia) seperti yang di sampaikan oleh Rasulullah:

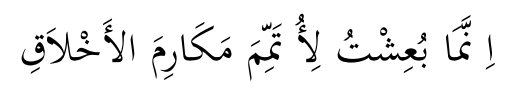

"Sesunggubnya saya diutus untuk menyempurnakan akblak", disitulah letak pentingnya ranah afektif pada pelajaran fikih harus disentuh dan dimaksimalkan .

Madrasah Aliyah Al Urwatul Wutsqo Bulurejo DIwek Jombang menerapkan pembelajaran Fiqih langsung bersumber pada Alqur'an yang biasanya disebut Tafsir

\footnotetext{
2 M.SlametYahya," AtmosfirAkademik dan Nilai-nilai Esetik Kitab Ta'lim al-Muta'allim. (P3M STAIN Porwokerto,2005). 2

${ }^{3}$ Fuad Hasan, Succan, Bebind The Scenes, StrategiPembelajaranAfektif, (2007) 3

${ }^{4}$ Ranah Afekif: Pengertian dan Aspek-aspek Serta Hubungannya, ,https;// www. Wawasan pendidikan. com/ 2016/ 08/diakses 10 pebruari 2018.
} 
Ahkam. Kebijakan ini disertai dengan harapan siswa akan dapat mengetahui dan mengamalkan ayat-ayat Alqur'an tentang hukum dalam kehidupan sehari-hari dengan mengetahui dasar hukum atau dalilnya. Penelitian ini bertujuan mendeskripsikan pembentukan ranah afektif siswa dalam pelajaran fiqih yaitu melalui pembentukan sikap dan kesadaran siswa Al Urwatul Wutsqo Bulurejo Diwek Jombang untuk menerapkan hukum Islam di dalam kehidupan sehari hari.

\section{PEMBAHASAN}

\section{A. Ranah Afektif}

1. Pengertian Ranah Afektif.

Istilah ranah afektif dalam bahasa Indonesia berasal dari kata "ranah" yang berarti "bagian (satuan) perilaku manusia" dan "Afektif" berarti "berkenaan dengan perasaan". Jadi ranah afektif merupakan bagian dari tingkah laku manusia yang berhubungan dengan perasaan. W.S. Winkel mengatakan bahwa salah satu ciri belajar afektif adalah belajar menghayati nilai dari suatu objek yang dihadapi melalui alam perasaan, entah objek itu berupa orang, benda atau kejadian/ peristiwa. Ciri yang lain terletak dalam belajar mengungkapkan perasaan dalam bentuk ekspresi yang wajar.

Sedangkan pembentukan ranah Afektif adalah suatu konsep yang berada dalam pikiran manusia yang sifatnya tersembunyi, tidak berada di dalam dunia empiris. Dengan demikian, pendidikan pembentukan ranah afektif kepada siswa pada dasarnya proses penanaman nilai perilaku kepada siswa yang diharapkan oleh karenanya siswa dapat berperilaku sesuai dengan pandangan yang dianggapnya baik dan tidak bertentangan dengan norma-norma yang berlaku. $^{6}$

2. Cara Pembentukan Ranah Afektif.

Tujuan utama pembentukan ranah afektif adalah untuk menjadikan anak didik memiliki budi pekerti yang luhur atau berakhlaqul karimah, maka

\footnotetext{
${ }^{5}$ Djalinus Syah, dkk., Kamus Pelajar (Kata Serapan Bahasa Indonesia), (Jakarta: Rineka Cipta, 1993), 4.

${ }^{6}$ Sanjaya Wina, M.Pd, Strategi Pembelajaran Berorientasi Standar Proses Pendidikan, Jakarta, Prenadamedia, 2006), 10
} 
diperlukan pembinaan terus menerus dan berkesinambungan di sekolah dengan cara :

a. Menciptakan situasi yang kondusif atau yang mendukung terwujudnya pembinaan aspek afektif pada diri siswa, yaitu: Dialogis, artinya komunikasi antara guru dengan siswa, antara orang tua dan guru, dapat dilakukan secara pribadi, kelompok, atau dengan seluruh siswa. Komunikatif, artinya apa saja yang akan dilaksanakan dan disampaikan oleh siswa maka tersampaikan kepada guru, wali kelas, kepala atau wakil kepala sekolah. Hal ini bertujuan untuk membantu memantau perkembangan siswa baik intelektual, sikap maupun aktualisasinya di luar sekolah yang tak terkontrol oleh guru. Keterbukaan, dialog atau komunikasi yang dilakukan secara terbuka, para siswa diberi kesempatan untuk mengembangkan pendapatnya.

b. Mengintegrasikan nilai nilai ranah afektif ke dalam mata pelajaran tertentu tidak menutup kemungkinan seluruh mata pelajaran yang lain

c. Peningkatan kerjasama dengan orang tua murid dan masyarakat.

3. Tahapan Ranah Afektif.

Menurut Krathwohl pembentukan ranah afektif dalam diri seseorang melalui klasifikasi atau tahapan sebagai berikut'

a. Receiving, terdiri: awareness (penyadaran), wiling to receive (kemampuan untuk menerima) dan controlled or selected attention (perhatian yang terkontrol atau terpilih yaitu aspek afektif, minat dan apresiasi). Pada tahap ini berhubungan dengan kepekaan siswa terhadap fenomena dan rangsangan dari luar seperti masalah, gejala, situasi, dll. ${ }^{8}$

b. Responding, terdiri dari: acquiescence is responding (persetujuan untuk menjawab), wilingness to respond (kemampuan untuk menjawab) dan satisfaction in respond (kepuasan untuk menjawab) (aspek afektif, minat, sikap, apresiasi, nilai \& penyesuaian). Tahap kedua ini siswa sudah memberi respon terhadap sebuah fenomena. Dalam kegiatan belajar mengajar terlihat adanya kemauan

7 David R. Krathwohl, Taxonomy of Educational Objectives; Handbook. II: Affective Domain, (London: Longman Group Ltd., 1956), 37

${ }^{8}$ Suke Silverius, Evaluasi Hasil Belajar dan Umpan Balik, (Jakarta: Grasindo, 1991), 49. 
siswa untuk menjawab pertanyaan guru, atau kepuasan dalam menjawab (misalnya membaca buku untuk kegembiraan".

c. Valuing, terdiri dari : acceptance of a value (penerima suatu nilai ), preference of a value (pemilihan suatu nilai), commitment (pertanggungjawaban untuk mengingatkan diri) (aspek afektif: minat, sikap, apresiasi, nilai, penyesuaian). Pada tahap ini, siswa sudah menghayati nilai-nilai tertentu. Hal ini terlihat pada perilaku siswa mulai dari penerimaan sebuah nilai, latar belakang atau pengalaman untuk menerima nilai dan kesepakaan terhadap nilai sehingga tingkah laku siswa konsisten dan memiliki keyakinan tertentu. ${ }^{10}$

d. Organization, yaitu menyatukan nilai-nilai yang berbeda, memecahkan konflik diantara nilai-nilai itu dan mulai membentuk suatu sistem nilai yang konsisten secara internal ${ }^{11}$.

e. Characterization by value complex, terdiri dari: generalized set (perangkat yang tergeneralisasi), kemudian characterization (karakterisasi) (aspek afektif : penyesuaian). Pada taraf ini disebut sebagai tahap internalisasi artinya suatu sistem nilai sudah terbentuk dalam diri individu dan mengontrol tingkah lakunya dalam waktu yang lama sehingga membentuk karakteristik "pola/pandangan hidup".

4. Aspek Ranah Afektif

a. Minat (Interest) adalah gejala psikis yang berkaitan dengan obyek atau aktivitas yang menstimulus perasaan senang pada individu". ${ }^{12}$ Jika seseorang senang terhadap obyek atau aktivitas tertentu maka ia akan mempunyai minat yang besar terhadapnya. Seorang siswa yang senang dengan pelajaran fikih, maka ia akan menaruh minat yang besar terhadap pelajaran tersebut, ia akan membaca buku-buku fikih, semangat dengan pelajaran fikih dll, sehingga bisa dipahami bahwa minat merupakan faktor pendorong bagi individu untuk melaksanakan usahanya.

\footnotetext{
${ }_{9}^{9}$ Amirul Hadi, dkk., Teknik Mengajar Secara Sistematis, (Jakarta: Rineka Cipta, 2001), 31.

${ }^{10}$ Slameto, Evaluasi Pendidikan, (Jakarta: Bumi Aksara, 2001), 162

${ }^{11}$ Suke Silverius, Evaluasi Hasil Belajar dan Umpan Balik, (Jakarta: Grasindo, 1991), 50

12 Wayan Nurkancana, Evaluasi Pendidikan, (Surabaya: Usaha Nasional, 1986), 229.
} 
b. Sikap (Attitude) adalah kecenderungan untuk merespon sesuatu baik individu, tata nilai, peristiwa, dan sebagainya dengan caracara tertentu. Sikap siswa dalam pembelajaran akan terlihat seperti adanya kemauannya untuk menerima pelajaran, memperhatikan terhadap penjelasan guru, menghargai guru. Maka dapat difahami bahwa sikap akan memberikan arah kepada seseoang untuk melakukan perbuatan yang positif ataupun negatif.

c. Nilai (V alue) adalah sesuatu yang bersifat abstrak ${ }^{13}$. Sedangkan pengertian nilai hubungannya dengan pembelajaran adalah ketika siswa mampu menghayati sebuah fenomena sehingga ia dapat membedakan benar dan salah, baik dan buruk dan mana yang lebih penting dalam hidup ${ }^{14}$.

d. Apresiasi, ini sering diartikan sebagai penghargaan terhadap suatu benda baik abstrak maupun kongkret yang memiliki nilai luhur dan umumnya dikaitkan dengan karya seni. Dalam proses belajar mengajar, Apresiasi dapat dilihat dari prilaku siswa dalam menghargai guru dan teman, menghargai waktu belajar dan memahami hal-hal yang lebih penting dalam hidup.

e. Penyesuaian (Adjustment). Diartikan sebagai penguasaan, yaitu kemampuan membuat rencana dan mengatur respon-respon sedemikian rupa sehingga dapat menguasai/menanggapi segala macam konflik atau masalah ${ }^{15}$. Sebagai contoh, siswa melakukan latihan dalam memecahkan masalah berdasarkan konsep dan bahan yang telah diperolehnya atau menggunakannya dalam praktek kehidupannya

5. Tujuan Pembentukan Ranah Afektif

a. Memberikan pemahaman tentang jati dirinya (self identity) sebagai makhluk hidup yang diciptakan oleh Allah yang mempunyai ketergantungan (dependent) dan sesama.

b. Memberikan pemahaman tentang tujuan hidup yakni mendapatkan ridla Allah SWT melalui iman, amal shaleh dan taqwa.

${ }^{13}$ M. Chabib Thoha, Kapita Selekta Pendidikan Islam, (Semarang: Pustaka Pelajar,1996), 60.

${ }^{14}$ Muhibbin Syah, Psikologi Pendidikan Dengan Pendekatan Baru, (Bandung: Rosdakarya, 1997), 121

${ }^{15}$ Kartini Kartono, Hygiene Mental dan Kesehatan Mental dalam Islam, (Bandung: Mandar Maju, 1989), 260261. 
c. Memberikan pemahaman tentang tugas dan fungsi hidup yakni beribadah kepada Allah SWT.

d. Memberikan pemahaman dan menyikapinya secara benar bahwa hidup di dunia ini berfluktuasi antara kebahagiaan dan kesusahan.

e. Memberikan pemahaman bahwa manusia mempunyai potensi rohaniah dalam dirinya, dan kiat-kiat dalam penglolaannya

f. Memberikan kesadaran untuk mengendalikan diri (self control)

g. Memberikan komitmen yang kuat untuk mewujudkan dirinya sebagai insan yang bermakna bagi kesejahteraan umat manusia

h. Memberikan keteguhan batin ${ }^{16}$

6. Metode Pengukuran Ranah Afektif.

a. Metode Observasi berdasarkan pada asumsi bahwa karateristik afektif dapat dilihat dari perilaku atau perbuatan yang ditampilkan dan/atau reaksi psikologi.

b. Metode laporan diri berasumsi bahwa yang mengetahui keadaan afektif seseorang adalah dirinya sendiri. Namun hal ini menuntut kejujuran dalam mengungkap karakteristik afektif diri sendiri.

\section{Model Pembentukan Ranah Afektif}

a. Model Konsiderasi, yaitu siswa didorong untuk lebih peduli, lebih memperhatikan orang lain, sehingga mereka dapat bergaul, bekerja sama, dan hidup secara harmonis dengan orang lain. Model ini dikembangkan oleh Mc. Paul, seorang humanis yang berpendapat bahwa pembentukan moral tidak sama dengan pengembangan kognitif yang rasional. Pembelajaran moral siswa adalah pembentukan kepribadian bukan pengembangan intelektual, sehingga penerapan strategi pembelajaran lebih ditekankan kepada pembentukan kepribadian agar siswa menjadi manusia yang memiliki kepedulian terhadap orang lain. ${ }^{17}$

\footnotetext{
${ }^{16}$ M.Yusuf Kadar,Tafsir Tarbawi Pesan-pesan Al-Qur'an tentang Pendidikan,(Jakarta: Amzah, 2015), ${ }^{17}$ Wina Sanjaya, Strategi Pembelajaran Berorientasi Standar Proses Pendidikan (Jakarta, Prenadamedia, 2006), 274
} 
b. Model Pengembangan Kognitif, yaitu perkembangan moral manusia berlangsung melalui restrukturalisasi atau reorganisasi kognitif yang berlangsung secara berangsur melalui tahap pra-konvensi dan post konvensi. Pendekatan ini mudah digunakan dalam proses pendidikan di sekolah, karena memberikan penekanan pada aspek perkembangan kemampuan berpikir, memberikan perhatian sepenuhnya kepada isu moral dan penyelesaian masalah yang berhubungan dengan pertentangan nilai tertentu dalam masyarakat, penggunaan pendekatan menjadi menarik dan dapat menghidupkan suasana kelas.

c. Pendekatan model analisis nilai (values analysis approach), yang memberikan penekanan pada perkembangan kemampuan siswa untuk berpikir logis, dengan cara menganalisis masalah yang berhubungan dengan nilai-nilai sosial yang berhubungan dengan nilai moral tertentu dan membantu siswa untuk menggunakan proses berpikir rasional dan analitik, dalam menghubunghubungkan dan merumuskan konsep tentang nilai-nilai mereka. Metoda ini sering digunakan dalam pembelajaran secara individu atau kelompok tentang masalah-masalah sosial yang memuat nilai moral, penyelidikan kepustakaan, penyelidikan lapangan, dan diskusi kelas berdasarkan atas pemikiran rasional ${ }^{18}$

d. Model Klarifikasi Nilai. Suatu model yang membantu siswa dalam mencari dan menentukan suatu nilai yang dianggap baik melalui proses menganalisis nilai yang sudah ada dan tertanam dalam diri siswa. Dengan pendekatan model ini, siswa tidak hanya disuruh menghapal dan disuapi dengan nilai-nilai yang sudah dirumuskan oleh pihak lain, melainkan mereka diajari untuk menemukan, menghayati, mengembangkan dan mengamalkan nilai-nilai hidupnya sendiri. ${ }^{19}$

e. Model Pembelajaran Berbuat. Model ini menekankan pada usaha memberikan kesempatan usaha kepada siswa untuk melakukan perbuatan-

18 Zakaria Ramli," Pendekatan-Pendekatan Pendidikan Nilai dan Implementasinya Dalam Pendidikan Budi Pekerti“Jurnal PendidikadaKebudayaan, (Jakarta, balitbang Depdiknas, okt, 2000, no 026), 18

${ }^{19}$ Zubaedi, Pendidikan Berbasis Masyarakat, (Jakarta: Pustaka Pelajar, 2000), 63. 
perbuatan moral, baik secara perseorangan maupun secara bersama-sama dalam suatu kelompok. ${ }^{20}$

\section{B. Pembelajaran Fikih}

\section{Dasar Pembelajaran Fikih}

Sebagai usaha untuk membentuk manusia dengan tujuan tertentu, maka pembelajaran Fikih mempunyai landasan yang kuat yaitu antara lain: Al Qur'an adalah firman Allah yang berupa wahyu yang di sampaikan oleh Jibril kepada Nabi Muhammad SAW. Di dalamnya terkandung 2 ajaran pokok agama Islam yaitu yang berhubungan dengan masalah keimanan (Aqidah) dan yang berhubungan dengan amal (syari'ah). Kemudian As-Sunnah adalah pekataan, perbuatan dan ketetapan Rasul Allah SWT. Dan Ijtihad, yaitu berfikir keras dengan menggunakan seluruh ilmu yang dimiliki oleh ilmuan syari'at Islam untuk menetapkan hukum syara'.

2. Prinsip Pembelajaran Fikih

Prinsip-prinsip hukum Islam menurut Juhaya S. Praja sebagai berikut :

a. Prinsip Tauhid, bahwa semua manusia ada dibawah satu ketetapan yang sama, yaitu ketetapan tauhid yang dinyatakan dalam kalimat La'ilaha Illa Allah (Tidak ada tuhan selain Allah), maka pelaksanaan hukum Islam merupakan perhambaan dan penyerahan diri pada Allah sebagai manivestasi rasa syukur kepada-Nya.

b. Prinsip Amar Makruf Nahi Mungkar, hukum Islam digerakkan untuk merekayasa umat manusia untuk menuju tujuan yang baik dan benar yang dikehendaki dan Ridho Allah dan menjauhi hal yang dibenci Allah.

c. Prinsip Keadilan,prinsip keadilan ketika dimaknai sebagai prinsip moderasi, menurut Wahbah Az-Zuhaili bahwa perintah Allah ditujukan bukan karena esensinya, sebab Allah tidak mendapat keuntungan dari ketaatan dan tidak pula mendapatkan kemadaratan dari perbuatan maksiat manusia. Namun ketaatan tersebut hanyalah sebagai jalan untuk

20 Zubaedi, Pendidikan Berbasis Masyarakat, (Jakarta: Pustaka Pelajar, 2000), 28-30 
memperluas prilaku dan cara pendidikan yang dapat membawa kebaikan bagi individu dan masyarakat.

d. Prinsip Kebebasan, keberagamaan dalam Islam dijamin berdasarkan prinsip tidak ada paksaan dalam beragama, tetapi berdasarkan penjelasan dan argumentasi. Kebebasan yang dimaksud adalah kebebasan individu maupun kebebasan komunal.

e. Prinsip Persamaan, prinsip persamaan ini merupakan bagian penting dalam pembinaan dan pengembangan hukum Islam dalam menggerakkan dan mengontrol sosial, tapi bukan berarti tidak pula mengenal stratifikasi sosial seperti komunis.

f. Prinsip Saling Tolong Menolong, prinsip bermakna saling membantu sesama manusia yang diarahkan sesuai prinsip tauhid, terutama dalam peningkatan kebaikan dan ketakwaan.

g. Prinsip Toleransi, prinsip toleransi yang dimaksud adalah toleransi yang menjamin tidak terlanggarnya hak-hak Islam dan umatnya. Toleransi hanya dapat diterima apabila tidak merugikan agama Islam sehingga tercipta masyarakat Rabbani.

h. Pola Pembelajaran Fikih, Alqurán adalah kitab petunjuk bagi kemaslahatan umat menusia, baik secara individual maupun social, maka ayat-ayat hokum merupakan bagian dari petunjuk-petunjuk yang ada di dalam Alqur'an. Untuk mengambil petunjuk dari ayat-ayat hukum dalam Alqur'an diperlukan pemahaman yang benar terhadap makna dan pesan yang dikandungnya. Namun memahaminya tidaklah semudah membalikkan telapak tangan sebab Alqurán selain berbahasa Arab juga memakai gaya bahasa dan sastra arab yang tinggi yang benar benar indah dan merdu (badi' dan baligh), yang tidak mungkin dapat di pahami dengan baik kecuali dengan penguasaan bahasa arab dan tata bahasanya, ilmu balaghah dan sastra Arab jahiliyah.

3. Strategi Pembelajaran Fikih

Strategi yang diterapkan dalam pembelajaran fikih antara lain adalah: 
a. Kegiatan Pendahuluan, yang bertujuan menciptakan suasana yang kondusif sehingga setiap siswa dapat belajar dalam harmoni dan kebersamaan.

b. Kegiatan Utama, merupakan kegiatan instruksional yang menekankan pada penciptaan pembelajaran yang harmoni untuk membentuk kepribadian siswa yang penuh dengan toleransi didasarkan pada perbedaan. Analisis, yaitu memberikan kesempatan kepada siswa untuk berbagi pemikiran dan pemahaman pribadi tentang sesuatu yang tidak dipelajarinya. Tahap ini perlu dilakukan dalam pembelajaran Fiqih karena melatih siswa untuk: mengungkapkan sesuatu secara objektif, melatih toleran terhadap pendapat yang berbeda, melatih menghargai pendapat orang lain, melatih kesabaran, meningkatkan keberanian dan tanggung jawab dalam melakukan kegiatan. Abstraksi, merupakan upaya pendidik untuk memperjelas materi inti yang harus dipahami oleh siswa. Penerapan, yaitu upaya pendidik dalam memberikan tugas kepada siswa untuk membuat catatan tersendiri tentang penerapan berbagai materi dalam aplikasi kehidupannya dengan penerapan pembelajaran multikultural yang bertujuan untuk mengukur perubahan yang terjadi pada siswa setelah mengikuti pembelajaran.

c. Kegiatan Penutup, dilakukan dengan mengevaluasi pengalaman yang diperoleh dalam pembelajaran, kemudian mengadakan penilaian.

4. Nilai Pembentukan Ranah Afektif dalam Pembelajaran Fikih

a. Nilai Andragogi. Guru adalah fasilitator bukan menggurui, sehingga relasi antar guru dan siswa bersifat multicommunication. Pendidikan dijadikan sebagai ajang kreativitas, minat, dan bakat siswa, visi pendidikan yang demokratis, liberatif, kemudian menjadi kebutuhan yang pokok ketika masih memiliki satu cita-cita tentang pentingnya membangun kehidupan yang humanis.

b. Nilai Perdamaian. Islam sebagai rabmatan lil alamiin, menyebarkan kedamaian kepada seluruh umat manusia. Islam melarang jihad terhadap orang-orang non Muslim yang menyatakan ingin hidup rukun dan damai bagi umat Islam. Sikap hidup damai bersama penganut agama lain telah 
dicontohkan oleh Nabi Muhammad SAW yang tidak melancarkan jihad terhadap orang minoritas, yaituYahudi karena mereka telah menyatakan diri untuk terikat dalam kontrak kenegaraan.

c. Nilai Inklusivisme. Menurut Abdullah Klaim-klaim sepihak sering muncul berkaitan dengan kebenaran suatu paham atau agama yang dipeluk seseorang atau masyarakat, bahwa hanya agama yang dianutnya atau agama tertentu yang benar sementara agama lain tidak dianggap tidak benar. Adapun dalam realitanya terdapat beragam agama dan keyakinan yang berkembang di masyarakat. Pluralitas agama, keyakinan dan pedoman hidup manusia adalah fakta sosial yang tidak dapat dimungkiri.

d. Nilai Kearifan. Menurut Machasin, Islam memberikan kebebasan kepada manusia untuk mencari sendiri berbagai hal yang dapat disebut prinsip sekunder. Dalam Islam kearifan dapat dipelajari melalui sufi yang berarti kebijakan atau kesucian yaitu suatu cara membersihkan hati dari kelakuan buruk. Sufi mengajarkan manusia untuk membersihkan nafsu, hati, dan jiwa melalui pendekatan esetoritas melihat Allah untuk dicintai.

e. Nilai Toleransi. Istilah toleransi berasal dari bahasa Inggris, yaitu Tolerance. Pendidik Fiqih perlu segera menampilkan ajaran-ajaran Islam yang toleran melalui kurikulum pendidikannya dengan tujuan menitikberatkan pada pemahaman dan upaya untuk bisa hidup dalam konteks berbeda agama dan budaya, baik secara individual maupun secar akelompok dan tidak terjebak pada primodialisme dan eksklusif kelompok agama dan budaya yang sempit.

f. Nilai Humanisme. Gerakan humanisme dan skolatisme telah memunculkan ortodoksi kebebasan. Selainitu, hukum keagamaan melahirkan teradi tertentu dalam pendidikan Islam, yaitu pendidikan Islam yang bisa dijadikan saluran transmisi dan inkulturasi keilmuan dan keabsahan hukum-hukum dalam kerangka ortodoksi. Berdasarkan hal tersebut, pendidikan Islam dinilai sebagai sistem sosial yang senantiasa merefleksikan filosofi komunitas pendudkungnya. Pendidikan dan pembelajaran yang bersifat aktif positif serta berdasarkan minta dan 
kebutuhan siswa sangat penting untuk memperoleh kemajuan, baik dalam bidang intelektual emosi, afeksi, maupun keterampilan yang berguna untuk hidup praktis.

g. Nilai Kebebasan. Menurut Driyakarta pendidikan adalah media kultural untuk membentuk manusia.hubungan anatara pendidikan dan manusia tidak dapat dipisahkan. Pendidikan sebagai media atau proses pembimbingan manusia muda menjadi dewasa, menjadi lebih manusiawi (humanior). Jalan yang ditempuh menggunkan missifikasi jalur kultural. Tidak ada model kapitalisasi pendidikan atau politisasi pendidikan, karena pendidikan secara murni berupaya murni membentuk insan akademis yang berwawasan dan berkepribadian manusia.

\section{ANALISIS}

\section{A. Pembelajaran Fikih di MA Al Urwatul Wutsqo Bulurejo Diwek Jombang}

Mata pelajaran Fikih di MA Al Urwatul Wutsqo Bulurejo Diwek Jombang terintegrasi dengan Tafsir Ahkam. Yaitu mempelajari langsung pada sumber hukum Islam yang pertama yaitu Alqurän. Secara khusus proses pembelajaran fikih hukumnya tidak terbatas artinya seluruh atau sebagian besar ayat-ayat Alqurán mengandung hukum yang menjadi sumber utama fikih Islam, dan sedapat mungkin menghindari perbedaan pendapat diantara para fuqaba', jikalau terdapat pendapat maka berlakulah pemikiran toleransi dan saling menghormati diantara perbedaan pendapat tersebut.

Secara umum proses pembelajaran fikih yang terintegrasi dengan Tafsir Ahkam di Al Urwatul Wutsqo Jombang sama dengan pembelajaran pelajaran lainnya. Yaitu dalam proses pembelajaran guru fikih dituntut untuk dapat mengelola pembelajaran yang mencakup perencanaan, pelaksanaan dan penilaian pembelajaran sebagaimana dalam Permendiknas RI No. 41 Tahun 2007 tentang standar proses.

1. Perencanaan: perencanaan yang dilakukan oleh guru fikih dengan menyusun perencanaan yang berisikan beberapa hal, yaitu tujuan yang akan dicapai, strategi untuk mencapai tujuan, sumber daya yang dapat mendukung sarana prasarana, dan praktek atau implementasi 
2. Pelaksanaan: pelaksanaan pembelajaran merupakan implementasi dari apa yang telah direncanakan dalam progam pembelajaran yang sebelumnya telah dibuat oleh guru fikih. Pelaksanaan pembelajaran ada tiga kegiatan utama yaitu, kegiatan pendahuluan, kegiatan inti dan kegiatan penutup

Dalam pelaksanaan pembelajaran fikih, guru mengajak para siswa untuk berinteraksi, dinamis dan dikendalikan oleh guru sebagai manajer pembelajaran. Guru akan menunjukkan ayat Alqur'an yang menjadi dasar atas hukum tertentu, kemudian dianalisa dari segi mufrodat (arti perkata), sebab nuzul dan hukum yang terkandung dalam ayat tersebut. Hal ini secara teknis dibutuhkan guru fikih yang menguasai beberapa hal, yaitu: pengelolaan tempat belajar/ruang kelas, pengelolaan bahan ajar, pengelolaan kegiatan dan waktu, pengelolaan siswa, pengelolaan sumber belajar, dan pengelolaan prilaku mengajar $^{21}$

Sehingga pelaksanaan pembelajaran merupakan inti dari pembelajaran karena di dalam pelaksanaan pembelajaran terdapat proses transfer materi yang melibatkan interaksi antara guru dengan peserta didik. Dalam pelaksanaan pembelajaran terdapat kegiatan pendahuluan, kegiatan inti dan kegiatan penutup yang akan mendukung tersampainya tujuan dari pembelajaran itu sendiri. Dalam pelaksanaan pembelajaran guru menerapkan model maupun strategi untuk dapat memahamkan peserta didiknya agar bisa tercapai tujuan dari sebuah pembelajaran.

3. Evaluasi: evaluasi digunakan sebagai salah satu komponen penting dalam pelaksanaan pendidikan Islam, evaluasi berfungsi untuk mengetahui apakah bahan yang telah diajarkan sudah dimiliki oleh peserta didik atau belum, untuk mendorong persaingan yang sehat antar peserta didik, untuk mengetahui kmajuan peserta didik setelah mengalami ajaran dan didikan, untuk mengetahui tepat atau tidaknya bahan, metode, dan berbagai penyesuaian dalam kelas yang telah dilakukan oleh guru, sebagai laporan terhadap orang tua peserta didik dalam bentuk raport, ijazah, piagam dan sebagainya. Evaluasi dalam mata pelajaran fikih ini dalam 2 bentuk lisan dan porto polio. Lisan meliputi

${ }^{21}$ M. Muslich, Pembelajaran Berbasis Kompetensi dan Kontekstual. (Jakarta: Bumi Akasara, 2007),72 
hafalan ayat-ayat hukum dalam alqur'an sesuai dengan tema pembahasan, dan porto polio berisikan penjelasan dan argumentasi hukum atas suatu kasus.

\section{B. Tujuan Pembelajaran Fiqih di MA Al Urwatul Wutsqo Bulurejo Diwek Jombang}

Tujuan pembelajaran fikih di MA Al Urwatul Wutsqo Jombang diantaranya untuk menumbuh kembangkan sikap, tingkah laku sesuai dengan aturan Allah dan Akhlak terpuji dalam kehidupan sehari-hari melalui tadarrus Alqur'an, hafalan $\mathrm{Al}$ qur'an, salat fardhu berjama'ah, pendalaman materi fiqih, salat malam berjama'ah, dan pendalaman materi agama melalui kultum setelah salat Subuh, pengajian Abah tiap ahad legi. Ranah Afektif bukan hanya sikap dan nilai saja yang diutamakan, tetapi meliputi hal penilaian sebuah fenomena dan dalam menuntun tingkah laku moralnya anak, dalam hal ini peran pesantren pendidikan non formalnya sangatlah besar, di samping anak-anak juga memperoleh pendidikan dijalur formalnya.

Pembentukan ranah afektif dimaksudkan mengugah emosi siswa agar berperan aktif seperti:

1. sikap keteladanan dari seorang guru mengajarkan pola hidup sederhana dan dicontohkan secara nyata dengan sikap dan perbuatan kesederhanaan, rendah hati dan jujur. Tidak sebaliknya. Siswa disuruh sederhana namun faktanya yang mereka lihat pada guru malah jauh dari kesederhanaan.

2. Pembiasaan diri, kebiasaan-kebiasaan unik dan positif dalam keluarga, pondok pesantren, lingkungan sekolah, dan masyarakat, perlu dikembangkan secara berkesinambungan. Misalnya, pemberian hukuman kepada anak/siswa yang melakukan kesalahan sebagai bukti tanggung jawab terhadap tingkah laku yang merugikan diri sendiri maupun oranglain. Pemberian penghargaan verbal maupun non verbal kepada anak/siswa yang melakukan kebiasaan baik.

3. Peraturan dan tata tertib, baik dalam keluarga, masyarakat tata tertib harus ditaati sehingga anak terbiasa untuk patuh dan taat pada setiap peraturan. Di lembaga sekolah sudah pasti memiliki peraturan. Hukuman dan sanksi yang diberikan kepada siswa yang melanggar mestilah bersifat mendidik dan memberi efek kesadaran diri. 


\section{Pembentukan Ranah Afektif dalam Pembelajaran Fikih di MA Al Urwatul Wutsqo Jombang}

Penerapan pembelajaran fikih menunjukkan suatu sikap pembentukan ranah Afektif nilai keagamaan, antara lain:

1. Penerapan Tingkat Penerimaan ( receiving). Setiap kegiatan pembelajaran Fiqih selalu di awali dan di akhiri dengan berdo'a dengan harapan semua perbuatan perkataan diniatkan hanya karena Allah semata. Pada tingkatan ini siswa memiliki keinginan dan kesiapan menerima pembelajaran Fikih sehingga tercermin sikap perilaku kehidupan sehari-hari yang dapat menjadikan manusia yang memiliki akal budi yang luhur. Pembentukan ranah afektif pada aspek receiving ,yang telah diterapkan kepada siswa dalam kategori baik, karena sudah banyak siswa-siswa yang telah menunjukkan ranah afektifnya baik di sekolah maupun di pondok pesantren.

Para siswa dalam menerima mata pelajaran fikih sudah mempunyai minat atau kesiapan untuk menerima (awareness) mata pelajaran fiqih. Juga sudah ada kemauan (willingness to receive) untuk belajar serta mereka juga mau memperhatikan atau fokus (controlled or selected attention) sebagai contoh tentang ibadah salat, anak anak belajar mengetahui dan memahami ,karena kebanyakan yang bersekolah di sini adalah anak rantau yang berasal dari daerah yang jauhjauh bahkan dari luar jawa, bahwa dalam melakukan ibadah sholat tidak harus kita di masjid ketika berada dalam perjalanan, dengan duduk, juga sudah bisa melakukan salat. Tidak ada air bukan penghalang untuk tidak sholat. Karena islam itu mudah. Yang penting baju yang kita pakai bersih, suci dan menutup aurot. Salatpun bisa diqosor sehingga bisa hanya 3 waktu, karena memang dibolehkan oleh Alqur'an.

2. Penerapan tingkat partisipasi ( responding). Dalam penerapan aspek partisipasi (responding) pada pembelajaran fikih di MA Al Urwatl Wutsqo Jombang dilakukan sebagai upaya pencapaian ranah afektif. Partisipasi aktif siswa sangatlah penting karena merupakan bagian perilaku yang menekankan pada pemerolehan respons, berkeinginan memberi respons, serta kepuasan dalam memberikan respons. Terlebih pada pembelajaran fikih yang terintegrasi dengan Tafsir Ahkam mencetak generasi muda yang memiliki pondasi Alqur'an, 
berkeyakinan kuat serta rasa persaudaraan dalam kebersamaan untuk melaksanakan amal kebaikan. Contoh ketika materi hukum makanan halal dan haram. Sebagai responnya siswa terbiasa memakan makanan yang di halalkan, karena tidak lain untuk menjaga kesucian dan kebaikan hati, akal, ruh dan jasad, yang mana baik buruknya keempat perkara ini sangat ditentukan setelah hidayah dari Allah SWT dengan makanan yang masuk ke dalam tubuh manusia yang kemudian akan berubah menjadi darah dan daging sebagai unsur penyusun hati dan jasadnya. Pemberian dorongan atau stimulus merupakan cara penerapan aspek partisipasi (responding) yang dilakukan guru mata pelajaran Fikih dalam pembentukan dan pencapaian ranah afektif siswa di kelasnya.

3. Penerapan tingkat penilaian/ penentuan sikap (V aluing). Penentuan nilai (Valuing), keyakinan atau sikap yang menunjukkan bahwa siswa sudah menghayati nilai-nilai Afektif yang terkandung dalam pembelajaran Fiqih. Siswa sudah menunjukkan minat, sikap, apresiasi, nilai, penyesuaian. Ini bisa terlihat dari keinginan siswa untuk meningkatkan ketrampilan, sampai pada tingkat komitmen atau bertanggungjawab untuk mengingatkan diri. Juga terlihat pada perilaku siswa mulai dari penerimaan suatu nilai, latar belakang atau pengalaman untuk menerima nilai dan kesepakatan, sehingga mereka memiliki keyakinan tertentu. Setiap akan memulai kegiatan siswa melakukan doa bersama.

Selain itu, siswa di anjurkan membawa kitab suci Alqur'an untuk kegiatan tadarus bersama yaitu saat mengawali pembelajaran juga melantunkan lagu lagu Qur'any. Siswa selain dibekali dengan penentuan pada nilai sikap (valuing) yang kuat diharapkan siswa mampu menghadapi segala persoalan hidup di masa yang akan datang. Sehingga penting dilakukan penerapan keagamaan yang akan membentuk siswa menjadi individu yang berpegang teguh kepada akidah Islam.

Pembentukan ranah afektif pada pembelajaran fikih di harapkan tumbuh dalam penentuan sikap valuing kebersamaan dalam menjalankan kebaikan. Serta menumbuhkan sikap valuing keikhlasan agar setiap perbuatan yang akan dilakukan selalu diawali dengan niat yang ikhlas hanya karena Allah. Do'a juga merupakan bentuk rasa syukur atas karunia yang diberikan Allah SWT kepada makhluk-Nya agar senantiasa mengingat Allah dan hanya kepada Allah manusia bergantung serta memohon pertolongan. 
4. Penerapan tingkat Organisasi (organization). Tingkat penerapan organisasi (organization) MA Al-Urwatul Wutsqo Bulurejo Jombang turut berperan penting dalam usaha ikut serta mencerdaskan kehidupan bangsa. Hal ini di buktikan melalui proses pembelajaran yang berlangsung selama ini, sehingga dapat mencetak kader-kader generasi yang memiliki spiritual keagamaan yang baik. Lingkungan siswa yang berbeda-beda tidak menjadi suatu halangan baik itu dari segi status sosial, ekonomi, bahkan dari budaya yang berbeda. Hal ini dikarenakan sebagian siswa yang berasal dari luar daerah, bahkan ada yang berasal dari luar pulau Jawa. Pembentukan ranah afektif dalam pembelajaran fikih membiasakan sikap keagamaan, diantaranya sholat fardhu berjama'ah, hafalan surat-surat di dalam Alqur'an, pendalaman materi fikih melalui pembelajaran baik di sekolah maupun di pondok pesantren melalui Kultum setelah sholat subuh. Pembentukan ranah afektif siswa merupakan usaha sadar dalam membentuk sikap dalam kehidupan sehari-hari.

Pembentukan ranah afektif pada aspek organisasi atau organization yang datangnya dari pribadi anak sendiri. Membangun nilai internal yang konsisten. Yang kedua adalah dari pihak keluarga, apabila keluarga sangat memperhatikan perkembangan pribadi anak pasti anak itu mempunyai ranah afektif sikap dalam berorganisasi menyelesaikan konflik antar nilai dan mulai membangun sistem nilai internal yang konsisten misalnya saja dalam pengembangan filsafat hidup. Faktor pendukung terakhir yaitu dari pihak lingkungan masyarakat, lingkungan masyarakat ini sangat berpengaruh sekali terhadap perkembangan afektif, apalagi anak yang emosinya masih labil atau bahasa jawanya "dhurung dhunve unggah-unggub".ini sangat berpengaruh sekali dalam penerapan aspek organisasi dalam ranah afektif.

Dari hasil wawancara dengan narasumber pada tingkat organisasi pembentukan ranah afektif siswa dalam pembelajaran tafsir ahkam anak berkeinginan untuk menilai hasil karya orang lain (konseptualisasi nilai). Melalui berorganisasi ,berinteraksi anak secara tidak langsung akan belajar menyesuaikan bagaimana bersikap , bertingkah laku agar bisa di terima oleh lingkungan dimanapun ia berada sesuai dengan kepentingan atau kesenangan pada masing- masing siswa. 
5. Penerapan tingkat pembentukan pola hidup (characterization). Ini merupakan tingkat ranah Afektif tertinggi, hasil pembelajaran pada tingkat ini berkaitan dengan pribadi, emosi, dan sosial anak, sehingga siswa mampu mengendalikan perilaku sampai pada waktu tertentu hingga terbentuk gaya hidup. Pembelajaran yang selama ini di lakukan oleh guru fikih khususnya dimulai dari awal pembentukan akidah yang kuat, maka akan terbentuk akhlak yang mulia. Ini tercermin dari perilaku siswa sehari-hari di lingkungan sekolah. Penerapan karakter afektif anak juga memerlukan upaya sadar dan sistematis. Perasaan, emosi, minat, sikap, dan apresiasi yang positif menimbulkan tingkah laku yang menunjukkan adanya kesenangan belajar. Memang tidak mudah, diperlukan kerja keras dari berbagai pihak, selain guru, orangtua dan masyarakat sangat berperan dalam perkembangan pribadi anak. Mengenai keaktifan dan keantusiasan siswa dalam pembentukan ranah afektif terutama sikapnya siswa sangat terlihat jelas, yaitu memiliki antusias dan disiplin yang tinggi dalam mengikuti pembelajaran fikih.

\section{KESIMPULAN}

Pembelajaran fikih di MA Al-Urwatul Wutsqo Jombang terintegrasi dengan Tafsir Ahkam, sehingga pembelajaran fikih merujuk langsung ke ayat-ayat Alqur'an tentang hukum. Pembentukan ranah afektif siswa dalam pembelajaran fikih di lakukan melalui tiga pendekatan integrative untuk menuju keberhasilan, yakni menghapus dikotomi (pemisahan ilmu dengan agama), membangun sinergi antar pelajaran, komitmen kolektif. Penerapan pembelajaran fikih menunjukkan suatu sikap pembentukan ranah afektif nilai keagamaan, antara lain: penerapan tingkat penerimaan, penerapan tingkat partisipasi, penerapan tingkat penilaian, penerapan tingkat organisasi, dan penerapan tingkat pembentukan pola hidup.

\section{DAFTAR PUSTAKA}

Chabib Thoha, M., Kapita Selekta Pendidikan Islam, Semarang: Pustaka Pelajar,1996.

Hadi, Amirul, dkk., Teknik. Mengajar Secara Sistematis, Jakarta: Rineka Cipta, 2001.

Hasan, Fuad, Succan, Bebind The Scenes, Strategi Pembelajaran Afektif, 2007. 
Kartono, Kartini, Hygiene Mental dan Kesehatan Mental dalam Islam, Bandung: Mandar Maju, 1989.

Khoiriyah, Memahami Metodologi Studi Islam, Yogyakarta; Penerbit Teras, 2013

Muslich, M. Pembelajaran Berbasis Kompetensi dan Kontekstual. Jakarta: Bumi Akasara, 2007.

Nurkancana, Wayan, Evaluasi Pendidikan, Surabaya: Usaha Nasional, 1986.

R. Krathwohl, David, Taxonomy of Educational Objectives; Handbook II: Affective Domain, London: Longman Group Ltd., 1956.

Ramli, Zakaria," Pendekatan-Pendekatan Pendidikan Nilai dan Implementasinya Dalam Pendidikan Budi Pekerti“'Jurnal PendidikadaKebudayaan, Jakarta, balitbang Depdiknas, okt, 2000, no 026.

Ranah Afekif: Pengertian dan Aspek-aspek Serta Hubungannya, ,https;// www. Wawasan pendidikan. com/ 2016/ 08/diakses 10 pebruari 2018.

Sanjaya, Wina, Strategi Pembelajaran Berorientasi Standar Proses Pendidikan. Jakarta, Prenadamedia, 2006.

Silverius, Suke, Evaluasi Hasil Belajar dan Umpan Balik, Jakarta: Grasindo, 1991.

Slameto, Evaluasi Pendidikan, Jakarta: Bumi Aksara, 2001.

SlametYahya, M, Atmosfir Akademik dan Nilai-nilai Esetik Kitab Ta'lim al-Muta'allim. P3M STAIN Porwokerto, 2005.

Syah, Djalinus, dkk., Kamus Pelajar (Kata Serapan Bahasa Indonesia), Jakarta: Rineka Cipta, 1993

Syah, Muhibbin, Psikologi Pendidikan Dengan Pendekatan Baru, Bandung: Rosdakarya, 1997.

Wina, Sanjaya, Strategi Pembelajaran Berorientasi Standar Proses Pendidikan, Jakarta, Prenadamedia, 2006.

Yusuf Kadar, M., Tafsir Tarbawi Pesan-pesan Al-Qur'an tentang Pendidikan, Jakarta: Amzah, 2015

Zubaedi, Pendidikan Berbasis Masyarakat, Jakarta: Pustaka Pelajar, 2000. 